were constructed. Such a base is inherently cheaper and quicker to construct than a normal base ; perhaps British engineers in the past have concentrated too much on the stabilization of the soil that happens to be on the site, and have given insufficient attention to the possibility of stabilizing low-grade unwashed gravel which may be available close by. Work on concrete and bituminous materials is also described.

The report begins with an attempt to gauge the importance of the road problem in Britain. The cost of road accidents is about $£ 100$ million a year, and that of time and fuel wasted in congested traffic is several times that figure. The present programme of road improvements is based on information that appears to be inadequate as a basis for design, and in comparison with the sums of money that have been mentioned above the expenditure on road research is negligible. The civil engineering industry itself does relatively little research, and the paucity of the support which the work of the Road Research Laboratory receives can be gauged from a disturbing sentence on the Alconbury Hill experimental section which ". . . was planned some twelve years ago" but was only constructed last vear. This is a straightforward experiment for which a site should have been found so that the work could be carried out well in advance of the present road-construction programme. It must be hard to continue with research that apparently receives slight encouragement, and know that for lack of design data the new roads that are now being built are probably not so good as they could be.

A. $N$. SCHofier.

\title{
JANE COFFIN CHILDS MEMORIAL FUND FOR MEDICAL RESEARCH
}

$\mathrm{T}$

HE Jane Coffin Childs Memorial Fund for Medical Research, of New Haven, Connecticut, made appropriations totalling $312,779.93$ dollars in support of research and fellowships in cancer for the year July 1, 1957-June 30, 1958. This brought to slightly more than four million dollars the total distributed by the Fund since its establishment in 1937.

Support is given by the Fund to research in both the basic and clinical sciences; for postdoctoral fellowships providing opportunity for advanced training and research; and for conferences and meetings of national and international societies concerned with cancer research. Among publications to the support of which the Fund has contributed since it helped to establish them are the journal, Cancer Research, and the "Atlas of 'Tumor Pathology".

Applications for research grants and fellowships are reviewed by the Board of Scientific Advisers, directed by Dr. M. C. Winternitz, three times a year at the offices of the Jane Coffin Childs Memorial Fund for Medical Research, 333 Cedar Street, New Haven 11, Connecticut.

Although most of the Fund's grants are given to American investigators, no geographical restrictions are placed on its allocations. Austria, Britain, France, Japan and Sweden are represented on the current list of grants for 1958. Dr. Bengt E. G. V. Sylvén, associate professor of experimental cancer research in the Karolinska Institute at Stockholm, received a first grant $(30,000$ dollars for three years) for development of cytochemical methods to be used in attacking a long-standing controversial question in cancer-the relation of proteolytic enzymes in the malignant cell to the penetration of surrounding tissues by cancer. Dr. Jacques Monod, director of the Department of Cellular Biochemistry at the Pasteur Institute, Paris, received a fifth grant (totalling 29,400 dollars since 1954) for studies of specific enzymes involved in the selective penetration of certain organic molecules into bacterial cells. Grants made to the Institute of Cancer Research, Royal Cancer Hospital, London, beginning in 1938 when the late Sir Ernest Kennaway, then director of the Institute, visited the Fund in New Haven, now total 73,500 dollars. American investigators supported by the Fund in 1958 were working chiefly in university and medical school departments of the basic and clinical sciences, ranging from genetics and botany to surgery and medicine.

Among the long-term programmes at present supported by the five-year grants is that of Dr. Charles B. Huggins and his associates ( 25,000 dollars a year) at the Ben May Laboratory of Cancer Research, University of Chicago.

In accordance with the developing trend in most of the research on cancer, biochemical approaches outnumber all others in the work of both investigators and Fellows supported by the Fund, with especial concern for the chemical reactions in normal and neoplastic cells and tissues and with particular interest in protein and nucleoprotein metabolism. These and other chemical approaches to the problems of cancer were being studied in tumour and other viruses, in immunological mechanisms, in connexion with the steroid hormones.

Among other grants made by the Fund for the first time in 1958 are those to Dr. L. L. Engel (Massachusetts General Hospital) for work on methods for studying urinary steroid metabolites in cancer: to Dr. E. H. Stotz (University of Rochester) to investigate the occurrence and role of peroxidase in proliferating tissue and its response to hormones; to Drs. R. W. McKee and H. Cook (University of California) for work on physico-chemical and biological characterization of nucleic acids and proteins from several different ascites tumours; to Prof. J. N. Davidson (University of Glasgow) to investigate nucleic acid metabolism in cancer tissue; to Dr. Osamu Hayaishi (Kyoto University) for work on the biological synthesis and degradation of peptides and proteins ; and to Dr. Stanfield Rogers (University of Tennessee) to investigate the mechanism of action of the Shope papilloma virus in producing papillomas in rabbit epithelium.

Now Fellows supported by the Fund in 1958 include Dr. P. Ottolenghi (Copenhagen). Dr. (G. L. Hagen (Harvard), Dr. M. Richter (Indiana), Dr. L. Del Gatto (California), Dr. E. V. W. Yamada (U.S. National Institute of Arthritis and Metabolic Diseases), Dr. K. R. Hanson (New York), Dr. Monto Ho (Harvard), Dr. D. Rubinstein (Michael Reese Hospital, Chicago), Dr. A. Iodice (University of California, Berkeley), Dr. E. A. Carusi (California Institute of Technology), Dr. J. Rothschild (Rockefeller Institute for Medical Research), Dr. J. B. Mudd (University of California, Berkeley). 